\title{
Flora of the cangas of the Serra dos Carajás, Pará, Brazil: Linderniaceae
}

\author{
André Vito Scatigna ${ }^{1,3}$ \& Nara Furtado de Oliveira Mota ${ }^{2}$
}

\begin{abstract}
This is a taxonomic study of the species of Linderniaceae from the cangas of the Serra dos Carajás, state of Pará, Brazil. Three species of Lindernia were recorded: L. brachyphylla, L. crustacea and L. diffusa, the first being restricted to South America and the two others with pantropical distribution. Here we present detailed descriptions, illustrations, photographs and notes on morphology, distribution and phenology of these species. Key words: Canga, FLONA Carajás, Scrophulariaceae, taxonomy.

\section{Resumo}

Este é um estudo taxonômico das espécies de Linderniaceae das cangas da Serra dos Carajás, no estado do Pará, Brasil. Foram registradas três espécies de Lindernia: L. brachyphylla, L. crustacea e L. diffusa, sendo a primeira restrita à América do Sul e as demais de distribuição Pantropical. Aqui, apresentamos descrições detalhadas, ilustrações, fotografias e comentários sobre morfologia, distribuição e fenologia destas espécies. Palavras-chave: Canga, FLONA Carajás, Scrophulariaceae, taxonomia.
\end{abstract}

\section{Linderniaceae}

Linderniaceae (Rchb.) Borsch, Kai Müll. \& Eb. Fisch. comprises ca. 15 genera and 200 species, occurring in the tropics. The largest genera are Lindernia All. (including Vandellia L., Bonnaya Link \& Otto, Ilysanthes Raf.), with ca. 100 species, and Torenia L., with ca. 40 species (Rahmanzadeh et al. 2005). The family presents great morphological diversity, from aquatic herbs to poikilohydric rupestrian subshrubs. Fischer et al. (2013) proposed a new circumscription of the genera, reducing Lindernia to ca. 30 species. In order to simplify the identification of taxa and to avoid classification issues, we adopted a broader circumscription of Lindernia (sensu Rahmanzadeh et al. 2005), also adopted by Souza \& Giulietti (2009) and the List of Species of the Brazilian Flora (BFG 2015). In the Serra dos Carajás, three species of Lindernia were collected in areas of canga.

\section{Lindernia All.}

Lindernia presents a great morphological diversity, from annual, aquatic or amphibian herbs - as some Brazilian species - to poikilohydric rupestrian subshrubs - several African species; flowers subsessile to longpedicelate, cleistogamous in some species; calyx campanulate, 5-lobed, weakly dentate to deeply divided; corolla strongly 2-lipped; stamens 2 or 4 , adaxial pair fertile, abaxial pair fertile or reduced to staminodes with capitate or filiform appendage. The distribution is pantropical, with three main geographical groups, two of them occurring in Southeastern Asia and Africa, with ca. 40 spp. each, followed by Central and South America, with seven spp., four of which in Brazil, usually associated with wet open areas (Philcox 1968; Fischer 2004; BFG 2015).

\footnotetext{
${ }^{1}$ Universidade Estadual de Campinas, Inst. Biologia, Prog. Pós-graduação em Biologia Vegetal, Postal Code: 6109, 13083-970, Campinas, SP, Brazil

${ }^{2}$ Museu Paraense Emílio Goeldi, Coord. Botânica, Prog. Capacitação Institucional, Av. Perimetral 1901, Terra Firme, 66077-830, Belém, PA, Brazil.

${ }^{3}$ Author for correspondence: andrescatigna@gmail.com
} 
Key to the species of Lindernia in the cangas of the Serra dos Carajás

1. Aquatic or amphibian; aerial leaves sessile, oval-lanceolate, falcate; pedicel 1.5-4.5 cm long; appendages of abaxial stamens strongly capitate, exserted ....................................... 1.1. Lindernia brachyphylla

1'. Terrestrial or amphibian; leaves sessile or petiolate, ovate to flabelliform; pedicel up to $0.9 \mathrm{~cm}$ long; appendages of abaxial stamens slightly capitate, included.....

2. Stem and leaves sub-glabrous to sparsely hispid-scabrous; leaf margin serrate; pedicel $0.4-0.9 \mathrm{~cm}$ long; capsule globose. 1.2. Lindernia crustacea

2'. Stem and leaves glabrous to pubescent; leaf margin serrulate; pedicel up to $0.1 \mathrm{~cm}$ long; capsule fusiform. 1.3. Lindernia diffusa

1.1. Lindernia brachyphylla Pennell, Fieldiana, Bot. 28(3): 519. $1953 . \quad$ Figs. 1a-f; 2a-b

Annual herbs, aquatic or amphibian, 3-40 $\mathrm{cm}$ long. Stems ascendant to erect, simple or branched, usually terete, glabrous. Aerial leaves usually opposite, rarely 3-8-whorled, glabrous, sessile, usually oval-lanceolate to lanceolate, falcate, apex and base acute, margin entire to sub-dentate, $0.3-1.3 \times 0.1-0.3 \mathrm{~cm}$; submerged 6-10-whorled, glabrous, linear, $0.3-2 \mathrm{~cm}$ long. Flowers axile, solitary; pedicel erect, sparsely glandular-pubescent towards apex, $1.5-4.5 \mathrm{~cm}$ long after anthesis, up to $5 \mathrm{~cm}$ after fructification. Sepals free, glandular-pubescent, lanceolate, apex acute, $0.2-0.5 \mathrm{~cm}$ long. Corolla white, pale blue to purple; tube externally glandular-pubescent, $0.4-0.9 \mathrm{~cm}$ long; lobes obovate, $0.2-0.8 \mathrm{~cm}$ long. Stamens 4 , abaxial pair strongly geniculate, appendage capitate, yellow, exserted. Ovary ellipsoid, style filiform, usually persistent. Capsule oval-ellipsoid $0.4-0.7 \mathrm{~cm} \times 0.2-0.4 \mathrm{~cm}$.

Material selected: Canaã dos Carajás, S11B, 6 20'36"S, $50^{\circ} 25^{\prime} 26^{\prime}$ 'W, 747 m, 27.I.2012, fl. and fr., L.V.C. Silva et al. 1128 (BHCB); S11D, 6⒉'31'’S, 5021'5 W, $820 \mathrm{~m}$, 18.V.2010, fl. and fr., M.O. Pivari et al. 1516 (BHCB); Serra da Bocaina, $6^{\circ} 18^{\prime} 35^{\prime}$ 'S, 49 $53^{\circ} 59^{\prime}$ 'W, $650 \mathrm{~m}$, 8.III.2012, fl. and fr., N.F.O. Mota et al. 2548 (BHCB, MG); Serra do Tarzan, $6^{\circ} 20^{\prime} 11^{\prime \prime} \mathrm{S}, 50^{\circ} 9^{\prime} 50^{\prime \prime} \mathrm{W}, 750 \mathrm{~m}$, 24.V.2010, fl. and fr., M.O. Pivari et al. 1567 (BHCB); Parauapebas [Marabá], N1, 17.III.1985, fl. and fr., R.S. Secco et al. 503 (HCSJ, MG); Parauapebas, N2, 6'3'20"S, $50^{\circ} 15^{\prime} 14^{\prime}$ 'W, m, 28.IV.2015, fl. and fr., N.F.O. Mota et al. 2965 (MG, UEC); N3, 6²'34”'S, 50²'29”'W, 688 m, 14.VI.2015, fl. and fr., N.F.O. Mota \& A.V. Scatigna 3370 (MG, UEC); N5, 6²’26”'S, 505'18”'W, 697 m, 15.VI.2015, fl. and fr., N.F.O. Mota \& A.V. Scatigna 3383 (MG); N7, 69'16”'S, 50¹0'18”'W, 696 m, 26.VI.2015, fl. and fr., N.F.O. Mota et al. 3433 (MG).

Lindernia brachyphylla is easily recognized by being an aquatic species with falcate sessile leaves (Figs. 1a and 2a), and by the appendage on abaxial stamens being strongly capitate, yellow and exserted (Fig. 2b). It presents leaf dimorphism (Fig. 1a), a feature not discussed elsewhere. The aerial leaves (Fig. 1c,d) are probably more adapted to photosynthesis and are perennial, whereas the submerged, whorled and long-linear shaped, leaves may be related to water and nutrient absorption and fall when the environment is dry. Lindernia brachyphylla has been collected in the Serra dos Carajás with flowers and fruits from January to June.

Lindernia brachyphylla has a South American distribution, occurring from Venezuela and Guyana to northern Brazil. In Brazil, it occurs in the states of Goiás, Mato Grosso, Pará and Roraima. Serra dos Carajás: Serra Norte: N1, N2, N3, N5 and N7; Serra Sul: S11B and S11D; Serra do Tarzan and Serra da Bocaina. Usually found in the edges of temporary lakes, and over fields with ironstone outcrops, which are periodically flooded, with part of the stem submerged.

1.2. Lindernia crustacea (L.) F.Muell., Syst. Census Austral. P1. 1: 97. 1882.

Capraria crustacea L. Syst. Nat. (ed. 12) 2: 419; Mant. pl. 1: 87. 1767.

Figs. 1g-j; 2c-d

Annual herbs, terrestrial or amphibian, $3-10 \mathrm{~cm}$ long. Stems prostrate, usually branched, quadrangular sparsely hispid-scabrous, hairs concentrated at the angles. Leaves opposite, glabrous to sparsely hispid-scabrous, usually glandular-punctate; petioles hispid-scabrous, $0.1-0.6 \mathrm{~cm}$ long; blade ovate, broadelliptical to flabelliforme, apex acute to obtuse, base cordate to obtuse, margin serrate, $0.3-1.3 \times 0.3-1.2$ $\mathrm{cm}$. Flowers axile and terminal, solitary; pedicel erect, glabrous to sparsely hispid-scabrous, $0.4-0.9 \mathrm{~cm}$ long after anthesis, up to $1.2 \mathrm{~cm}$ after fructification. Sepals fused, free after fructification, hispid-scabrous, ribbed, elliptical, apex acute to acuminate, $0.2-0.4 \mathrm{~cm}$ long. Corolla white, purple to pale blue; tube externally glabrous, $0.3-0.6 \mathrm{~cm}$ long; lobes obovate to rounded, $0.1-0.3 \mathrm{~cm}$ long. Stamens 4 , abaxial pair with slightly capitate appendage, white, included. Ovary ellipsoid, style filiform, usually persistent. Capsule globose $0.3-0.5 \times 0.2-0.5 \mathrm{~cm}$. 


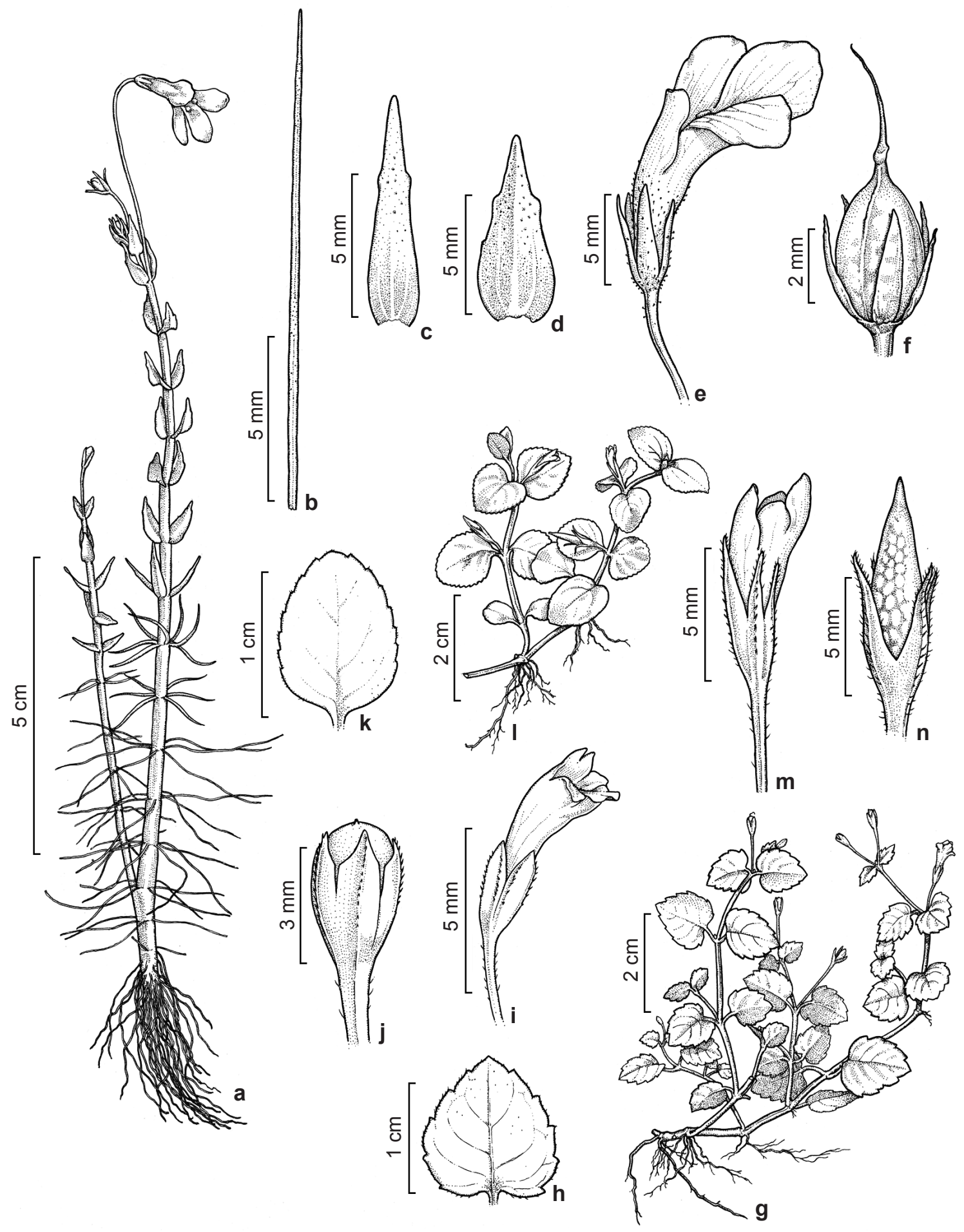

Figure 1 - a-f. Lindernia brachyphylla - a. habit; b. submerged, long-linear leaf; c-d. aerial leaves; e. flower in detail; f. fruit in detail. g-j. Lindernia crustacea - g. habit; h. leaf in detail; i. flower in detail; j. fruit in detail. k-n. Lindernia diffusa - k. habit; 1. leaf in detail; m. flower in detail; n. fruit in detail (a-f. N.F.O. Mota \& A.V. Scatigna 3370; g-j. N.F.O. Mota et al. 2611; k-n. N.F.O. Mota et al. 3431). Illustrations by João Silveira. 
Material selected: Canaã dos Carajás: S11D, 6²3'48'S, $50^{\circ} 20^{\prime} 58^{\prime \prime} \mathrm{W}, 757$ m, 30.I.2012, fl. and fr., L.V.C. Silva et al. 1196 (BHCB); Serra da Bocaina, 6¹8'38"S, 49॰54'9"'W, $650 \mathrm{~m}, 11$. III.2012, fl. and fr., N.F.O. Mota et al. 2611 (BHCB); Serra do Tarzan, 6¹9'56"S, $50^{\circ} 8^{\prime} 57^{\prime \prime} \mathrm{W}, 750 \mathrm{~m}, 24$.V.2010, fl. and fr., M.O. Pivari et al. 1582 (BHCB); Parauapebas: N4-WS, 66'49”S,
50¹1'4"'W, 687 m, 20.IV.2012, fl. and fr., A.J. Arruda et al. 979 (BHCB); N5, 24.I.1990, fl. and fr., R.R. Martins \& J.P. da Silva 677 (HCSJ, MG).

Lindernia crustacea is similar to L. diffusa in habit and shape, differing from it by the indument being hispid-scabrous (vs. pubescent); leaf margin serrate ( $v s$. serrulate; Figs. 11 and $2 \mathrm{~d} v s .1 \mathrm{~h}$ and $2 \mathrm{e}$,
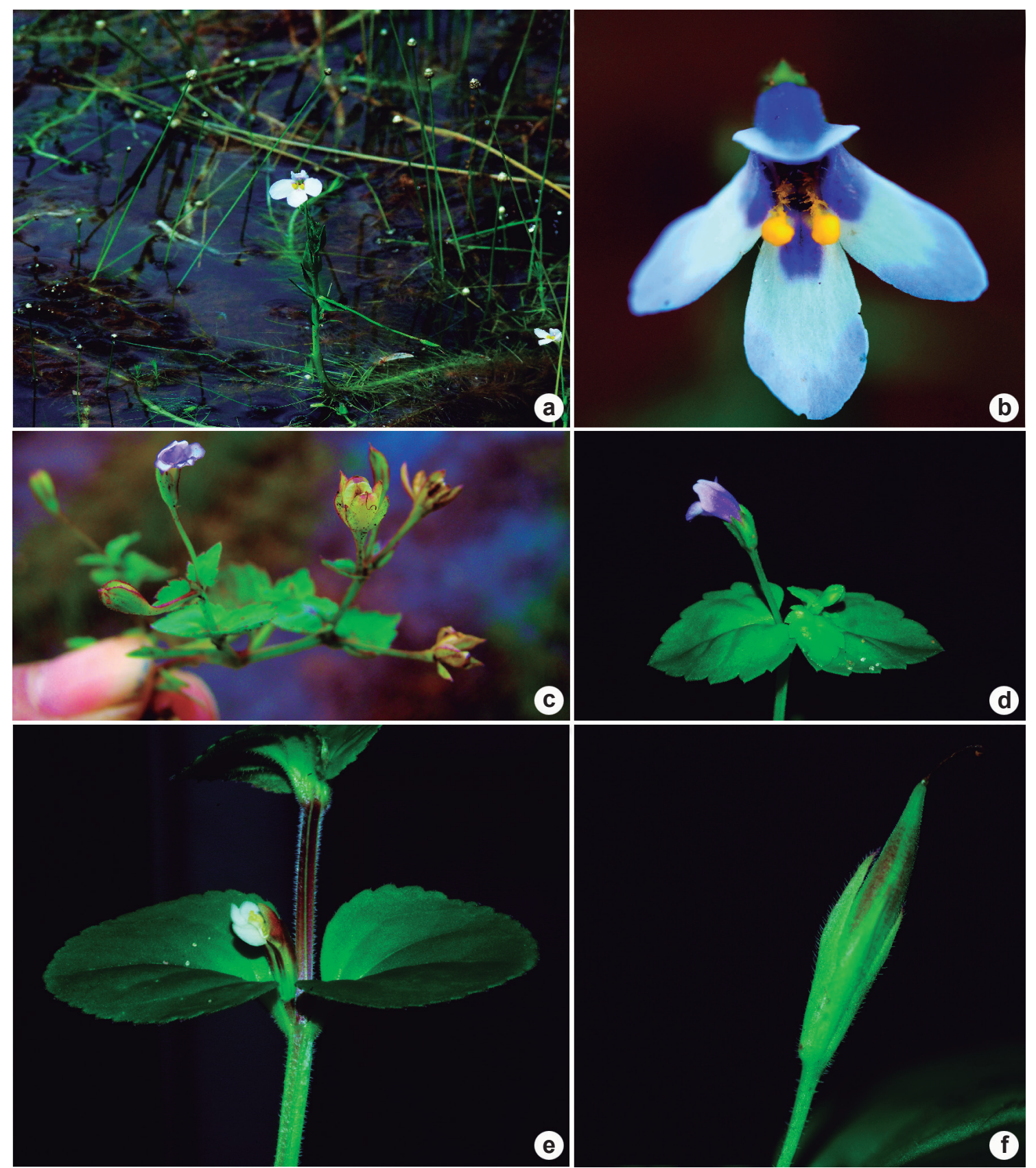

Figure 2 -a-b. Lindernia brachyphylla - a. specimen in flooded habitat; b. flower in apical view with yellow stamen appendages. c-d. Lindernia crustacea - c. habit; d. flowering stem and leaves. e-f. Lindernia diffusa-e. flowering stem and leaves; f. fruit in detail. Photos a, c-f. N.F.O. Mota; b. P.L. Viana 
respectively); longer pedicel (0.4-0.8 cm vs. up to $0.1 \mathrm{~cm}$; Figs. $1 \mathrm{k}$ and $2 \mathrm{c} v s .1 \mathrm{~g}$ and $2 \mathrm{e}$, respectively); and capsule globose ( $v s$. fusiform; Figs. In $v s .1 \mathrm{j}$ and $2 \mathrm{f}$, respectively). Lindernia crustacea has been collected in the Serra dos Carajás with flowers and fruits from December to May.

Lindernia crustacea exhibits a pantropical distribution. In Brazil, it occurs in all states of the North and West-Central regions, also in Maranhão, Ceará, Paraíba, Pernambuco, Sergipe, and Bahia, in the Northeast region, and in São Paulo in Southeast region. Serra dos Carajás: Serra Norte: N4-WS and N5; Serra Sul: S11D; Serra do Tarzan and Serra da Bocaina. Found in wet open areas, close to flooded fields or disturbed areas as roads and forest borders.

1.3. Lindernia diffusa (L.) Wettst. in Engl. \& Prantl, Nat. Pflanzenfam. 4 (3b): 79. 1891.

Vandellia diffusa L. Syst. Nat. (ed. 12) 2: 422; Mant. pl. 1: 89. 1767.

Figs. 1k-n; 2e-f

Annual herbs, terrestrial, $10 \mathrm{~cm}$ long. Stems branched, usually quadrangular, prostrate, pubescent. Leaves opposite, glabrous to pubescent, sessile to sub-sessile; petiole max. $0.3 \mathrm{~cm}$ long, ovate to broad-elliptical, apex obtuse to round, base obtuse to truncate, margin serrulate, 0.8-1.5 $\times 0.7-1.4 \mathrm{~cm}$. Flowers axile, solitary, sub-sessile; pedicel $0.1 \mathrm{~cm}$ long after anthesis, up to 0.2 $\mathrm{cm}$ after fructification. Sepals free, pubescent, lanceolate, apex acute, $0.4-0.5 \mathrm{~cm}$ long. Corolla white, pinkish to pale blue; tube externally glabrous, ca. $0.5 \mathrm{~cm}$ long; lobes sub-orbicular, $0.1-0.2 \mathrm{~cm}$ long. Stamens 4 , abaxial pair with short appendage, white, included. Ovary ellipsoid, style filiform, persistent. Capsule hispid-puberulous towards apex, fusiform, apex acuminate, 0.8-1 $\times 0.2 \mathrm{~cm}$.

Material selected: Parauapebas: N4, 66'18"S, $50^{\circ} 10^{\prime} 57^{\prime \prime} \mathrm{W}, 692$ m, 26.VI.2015, fr., N.F.O. Mota et al. 3431 (MG).

Only one specimen of Lindernia diffusa was analyzed. For morphological comparison, see notes under L. crustacea. Lindernia diffusa has been collected in the Serra dos Carajás with flowers and fruits in June.

Lindernia diffusa has a pantropical distribution. In Brazil, it occurs from the state of Roraima to Santa Catarina. Serra dos Carajás: Serra Norte: N4 Plateau. Found in wet open areas, close to flooded fields or disturbed areas as roads and borders of forests.

\section{Acknowledgements}

The first author thanks the Programa de Pós-graduação em Biologia Vegetal of UNICAMP for the Ph.D. scholarship. The second author thanks the Programa de Capacitação Institucional (MPEG/MCTI) for the grant. We thank Instituto Tecnológico Vale (01205.000250/2014-10) and CNPq (455505/2014-4) for financial support and João Silveira for the line drawings.

\section{References}

BFG. 2015. Growing knowledge: an overview of seed plant diversity in Brazil. Rodriguésia 66: 10851113.

Fischer, E. 2004. Scrophulariaceae. In: Kadereit, J.W. (ed.). The families and genera of vascular plants 7 . Flowering plants. Dicotyledons. Lamiales (except Acanthaceae including Avicenniaceae). Springer, Berlin, Heidelberg, New York. Pp. 333-432.

Fischer, E.; Schäferhoff, B. \& Müller, K. 2013. The phylogeny of Linderniaceae - The new genus Linderniella, and new combinations within Bonnaya, Craterostigma, Lindernia, Micranthemum, Torenia and Vandellia. Willdenowia 43: 209-238.

Philcox, D. 1968. Revision of the Malesian species of Lindernia All. Kew Bulletin 22: 1-72.

Rahmanzadeh, R.; Müller, K.F.; Fischer, E.; Bartels, D. $\&$ Borsch, T. 2005. Linderniaceae and Gratiolaceae (Lamiales) are further lineages distinct from Scrophulariaceae. Plant Biology 7: 67-78.

Souza, V.C. \& Giulietti, A.M. 2009. Levantamento das espécies de Scrophulariaceae sensu lato nativas do Brasil. Pesquisas, Botânica 60: 7-288.

\section{List of exsicates}

Arruda, A.J. 1022 (1.1), 979 (1.2); Lobato, L.C. 4365 (1.1); Martins, R.R. 677 (1.2); Mayer, P.B. 1228, 1244 (1.1); Mota, N.F.O. 2548 (1.1), 2611 (1.2), 2953, 2965, 3370, 3383 (1.1), 3431 (1.3), 3433 (1.1); Paula , L.F.A. 487 (1.2); Pivari, M.O. 1500, 1516, 1567 (1.1), 1582, 1701 (1.2); Rosa, N.A. 493, 5131 (1.1); Secco, R.S. 503 (1.1); Silva, L.V.C. 1128 (1.1), 1196 (1.2), 1323 (1.1); Tyski, L. 54 (1.2). 
